\title{
Electrolysis of Converter Matte in Molten $\mathrm{CaCl}_{2}$-NaCl
}

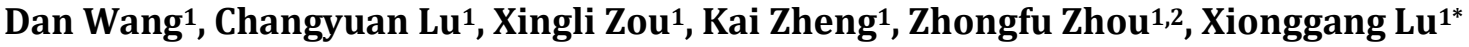 \\ ${ }^{1}$ State Key Laboratory of Advanced Special Steel \& Shanghai Key Laboratory of Advanced Ferrometallurgy, School of Materials \\ Science and Engineering, Shanghai University, Shanghai, China \\ ${ }^{2}$ Department of Physics, Aberystwyth University, Aberystwyth, UK \\ Email: *luxg@m ail.shu.edu.cn
}

How to cite this paper: Wang, D., Lu, C.Y., Zou, X.L., Zheng, K., Zhou, Z.F. and Lu, X.G. (2018) Electrolysis of Converter Matte in Molten $\mathrm{CaCl}_{2}-\mathrm{NaCl}$. Journal of Materials Science and Chemical Engineering, 6, 1-11.

https://doi.org/10.4236/msce.2018.62001

Received: January 15, 2018

Accepted: February 9, 2018

Published: February 12, 2018

Copyright (C) 2018 by authors and Scientific Research Publishing Inc. This work is licensed under the Creative Commons Attribution International License (CC BY 4.0).

http://creativecommons.org/licenses/by/4.0/

\begin{abstract}
The electrolytic production of nickel-copper alloy by electrochemical reduction of converter matte in molten salt has been investigated. The sintered solid porous pellets of $\mathrm{Ni}_{3} \mathrm{~S}_{2}, \mathrm{Cu}_{2} \mathrm{~S}$ and converter matte were electrolyzed at a voltage of $3.0 \mathrm{~V}$ in molten $\mathrm{CaCl}_{2}-\mathrm{NaCl}$ under the protection of argon gas at $700^{\circ} \mathrm{C}$, respectively. The electro-reduction processes were investigated and the products were characterized. The results show that the molten salt electroreduction process can be used to produce nickel, copper and nickel-copper alloy directly from $\mathrm{Ni}_{3} \mathrm{~S}_{2}, \mathrm{Cu}_{2} \mathrm{~S}$ and converter matte precursors in molten $\mathrm{CaCl}_{2}-\mathrm{NaCl}$, respectively. $\mathrm{CaS}$ would be formed as the intermediate compound during the electro-reduction process, and then the formed $\mathrm{CaS}$ can be gradually decomposed and removed with the increase of the electrolysis time. The experimental results show that the molten salt electro-reduction process has the potential to be used for the reduction of sulfide minerals in molten $\mathrm{CaCl}_{2}-\mathrm{NaCl}$.
\end{abstract}

\section{Keywords}

Converter Matte, Electro-Reduction, Nickel-Copper Alloy, Molten $\mathrm{CaCl}_{2}-\mathrm{NaCl}$, Solid-State Electrochemistry

\section{Introduction}

Nickel-copper alloy is a high-quality corrosion-resistant alloy with good corrosion resistance in seawater, acid, alkali and reducing gas atmosphere [1] [2] [3] [4] [5]. Nickel-copper alloy has high commercial value due to its excellent manufacturability and mechanical property. In the conventional smelting process for nickel-copper alloy production, pure nickel and copper metals should be 
firstly produced from minerals and then alloyed together to form nickel-copper alloy. Generally, this conventional method needs complex and energy-intensive processes.

So far, over $90 \%$ of the world's primary copper on the earth's crust is present in the form of copper sulfide minerals, and about $50 \%$ of the world's primary nickel production starts from nickel sulfide ores [6] [7] [8]. Meanwhile, most of the nickel sulfide ores are inevitably associated with copper sulfides [9] [10] [11]. In the traditional pyrometallurgical process, the sulfide ores are mined, reduced in size, and floated to produce nickel- and copper-rich concentrates. Then, the concentrates are smelted in flash smelter or electric furnace to produce nickel-copper matte. Subsequently, the nickel-copper matte is smelted and converted into converter matte, the converter matte is commonly dominated by nickel and copper sulfides with a small amount of iron sulfide. After that, the converter matte is separated into nickel concentrate and copper concentrate by flotation. Then, the nickel and copper concentrates are fabricated into $\mathrm{Ni}_{3} \mathrm{~S}_{2}$ and $\mathrm{Cu}_{2} \mathrm{~S}$ anodes for the electrolysis in aqueous electrolyte to produce $\mathrm{Ni}$ and $\mathrm{Cu}$, respectively [12] [13] [14]. It is obvious that the traditional process is complex. In addition, this process may also be suffered from the limited electrochemical window of the aqueous electrolyte and the large ohmic polarisation caused by the non-conducting sulfur deposited on the anode [15].

In recent years, a generic process for producing metals and alloys by direct electrochemical reduction of metal oxides or their mixtures has attracted worldwide attention [16]. Many efforts have been devoted to the direct reduction of metal oxides [17]-[25]. Actually, many metal sulfides are thermodynamically less stable than their oxide compounds [26]. Recently, some researchers have investigated the electro-reduction of sulfides in molten salts [6] [15] [27] [28]. Li et al. [27] investigated the electrolysis of $\mathrm{MoS}_{2}$ in molten $\mathrm{CaCl}_{2}$. Chen et al. [28] examined the removal of $\mathrm{S}$ in liquid copper. Ge et al. [6] studied the electrochemical extraction of copper from copper sulfide in molten $\mathrm{CaCl}_{2}-\mathrm{NaCl}$. Wang et al. [15] investigated the electrolysis of $\mathrm{WS}_{2}$ to metal $\mathrm{W}$ in molten $\mathrm{NaCl}-\mathrm{KCl}$. However, these previous work generally focused on pure metal sulfides, the direct electrochemical reduction of sulfide minerals in molten salts needs more investigation.

In the present work, the electro-reduction process has been used to directly extract nickel-copper alloy from converter matte in molten $\mathrm{CaCl}_{2}-\mathrm{NaCl}$ at $700^{\circ} \mathrm{C}$. This work will show that the converter matte can be reduced to nickel-copper alloy in molten salts. The results generally suggest that the molten salt electro-reduction process is a promising process for the facile reduction of sulfide minerals in molten $\mathrm{CaCl}_{2}-\mathrm{NaCl}$.

\section{Experimental}

Figure 1(a) shows the XRD pattern of the converter matte used in this experiment. Obviously, the converter matte is composed of $\mathrm{Ni}_{3} \mathrm{~S}_{2}$ and $\mathrm{Cu}_{2} \mathrm{~S}$. Figure 1 (b) shows the SEM image of the cross section of the initial converter matte. 


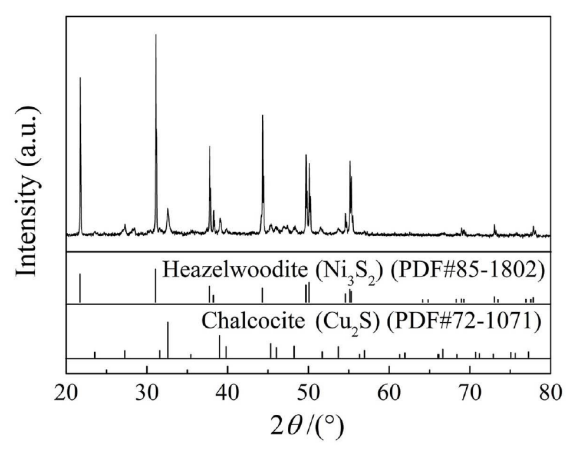

(a)

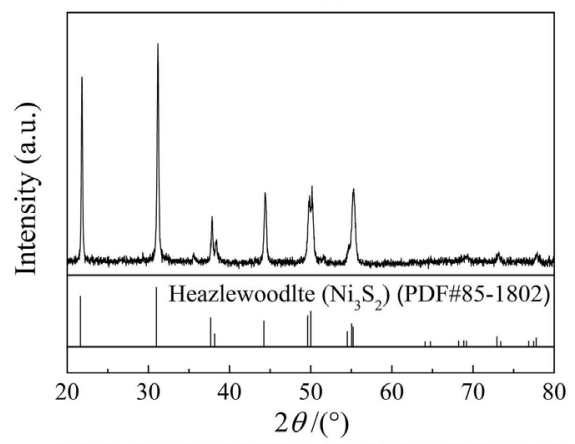

(c)

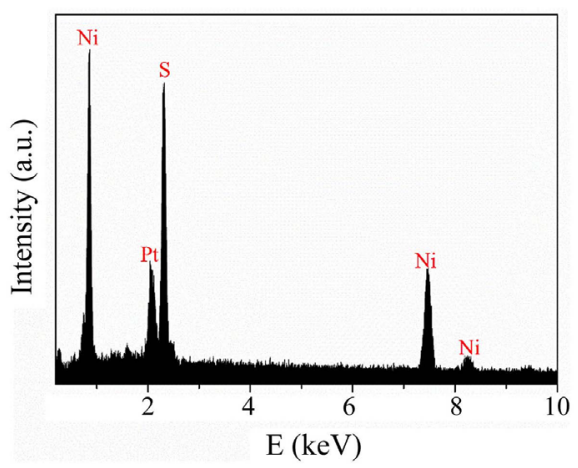

(e)

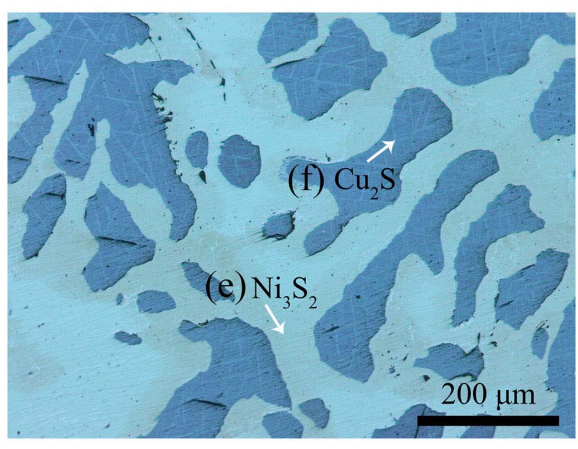

(b)

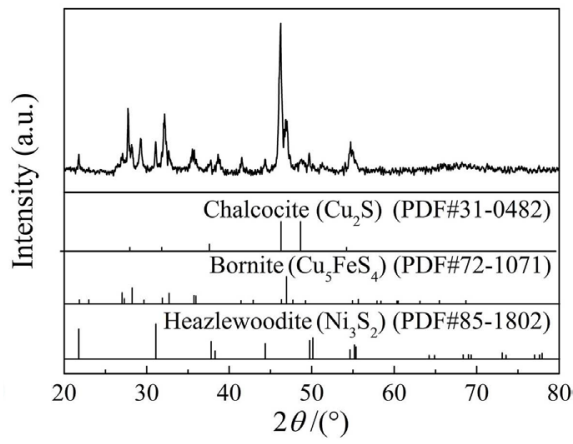

(d)

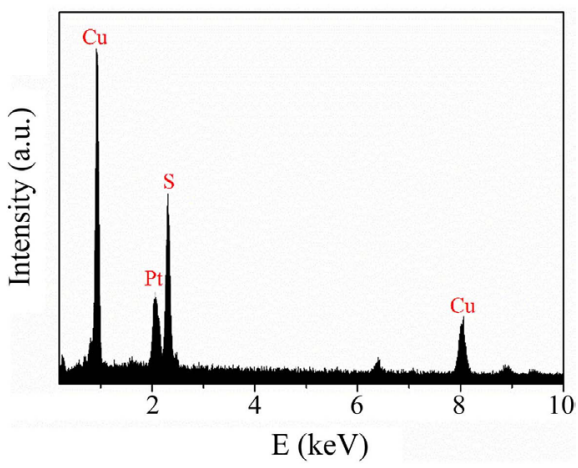

(f)

Figure 1. (a) XRD pattern and (b) SEM image of converter matte, (c) and (d) XRD patterns of $\mathrm{Ni}_{3} \mathrm{~S}_{2}$ (c) and $\mathrm{Cu}_{2} \mathrm{~S}(\mathrm{~d})$, (e) and (f) EDS results of watchet area (e) and mazarine area (f) in (b).

Two phases with different colors (mazarine and watchet) are observed, the EDS results ofwatchet area and mazarine areain Figure 1(b) are shown in Figure 1(e) and Figure 1(f), respectively. It is observed that the phase with mazarine is determined as $\mathrm{Cu}_{2} \mathrm{~S}$ and the phase with watchet is confirmed to be $\mathrm{Ni}_{3} \mathrm{~S}_{2}$. In addition, the $\mathrm{Ni}_{3} \mathrm{~S}_{2}$ and $\mathrm{Cu}_{2} \mathrm{~S}$ separated from the converter matte were also used as the starting cathode materials for comparison. The phase compositions of the $\mathrm{Ni}_{3} \mathrm{~S}_{2}$ and $\mathrm{Cu}_{2} \mathrm{~S}$ are shown in Figure $1(\mathrm{c})$ and Figure 1(d), respectively. As shown in Figure $1(\mathrm{~d})$, the $\mathrm{Cu}_{2} \mathrm{~S}$ sample contains a small amount of $\mathrm{Ni}_{3} \mathrm{~S}_{2}$ and $\mathrm{Cu}_{5} \mathrm{FeS}_{4}$. The chemical compositions of these initial samples $\left(\mathrm{Ni}_{3} \mathrm{~S}_{2}, \mathrm{Cu}_{2} \mathrm{~S}\right.$ and converter matte) used in the present study are listed in Table 1. 
Table 1. Table type styles (Table caption is indispensable).

\begin{tabular}{ccccccc}
\hline Component & $\mathrm{Ni}$ & $\mathrm{Cu}$ & $\mathrm{S}$ & $\mathrm{Fe}$ & $\mathrm{O}$ & other \\
\hline Converter matte & 43.77 & 31.83 & 18.54 & 3.24 & 1.88 & 0.74 \\
$\mathrm{Ni}_{3} \mathrm{~S}_{2}$ & 65.18 & 4.66 & 19.57 & 2.30 & 6.01 & 2.28 \\
$\mathrm{Cu}_{2} \mathrm{~S}$ & 5.09 & 67.74 & 16.66 & 6.51 & 3.75 & 0.25 \\
\hline
\end{tabular}

The schematic diagram of the electrolytic cell used for the electro-reduction experiment is shown in Figure 2. The anhydrous $\mathrm{CaCl}_{2}$ and $\mathrm{NaCl}$ were weighed and mixed at the molar ratio of $1: 1$. The $\mathrm{CaCl}_{2}-\mathrm{NaCl}$ mixture was filled in an alumina crucible (55 $\mathrm{mm}$ in diameter, $120 \mathrm{~mm}$ in height) and served as electrolyte. The converter matte was firstly ball-milled and screened to obtain homogenous powders with particle size below $75 \mu \mathrm{m}$. Then, about $1.0 \mathrm{~g}$ of the converter matte powder was pressed into pellet with a diameter $8 \mathrm{~mm}$ under a pressure of $10 \mathrm{MPa}$, the pressed pellet was sintered in argon gas at $400^{\circ} \mathrm{C}$ for $2 \mathrm{~h}$. Similar procedures were also used to fabricate the $\mathrm{Ni}_{3} \mathrm{~S}_{2}$ and $\mathrm{Cu}_{2} \mathrm{~S}$ pellets. The sintered pellet was wrapped with thin stainless steel nets (pore size of $75 \mu \mathrm{m}$ ) and then attached to a Fe-Cr-Al wire ( $2 \mathrm{~mm}$ diameter) to form a cathode. A graphite rod (12 mm diameter) was used as an anode. The electrochemical experiments were controlled by using a BioLogic HCP-803 electrochemical workstation. Argon gas (99.99\%) was used to maintain an inert atmosphere during electrolysis process.

During the electrolysis process, sulphur in cathode may get ionized and transport to the anode, which may cause the precipitation of $\mathrm{CaS}$ [6]. A high voltage of $3.0 \mathrm{~V}$ is adopted to promote the decomposition of CaS. After being electrolyzed at $3.0 \mathrm{~V}$ at $700^{\circ} \mathrm{C}$ in molten $\mathrm{CaCl}_{2}-\mathrm{NaCl}$ for an appropriate time, the cathode was lifted and cooled in argon gas above the molten salt. Then, the cathode was taken out and washed by distilled water. The washed cathode product was dried and collected. The morphology of the obtained products was characterized by using a scanning electron microscope (SEM, JSM-6700F, JEOL Ltd., Japan) at an acceleration voltage of $15 \mathrm{kV}$. The elemental composition of the samples was analyzed by using an energy-dispersive X-ray spectroscopy (EDS, Oxford Inca, Oxfordshire, UK) attached to the SEM and also by an inductively coupled plasma optical emission spectrophotometer (ICP-OES, PerkinElmer Optima 7300 DV, Connecticut, USA). The phase composition of the samples was determined by a powder X-ray diffractometer (XRD, D8 Advance, Bruker, Germany) with $\mathrm{Cu} \mathrm{Ka}$ radiation.

\section{Results and Discussion}

The typical current-time curve recorded during the electrolysis process of $\mathrm{Cu}_{2} \mathrm{~S}$ is presented in Figure 3(a). The current shows a drop within the first $1 \mathrm{~h}$. Then, the current gradually decreases to about $0.2 \mathrm{~A}$ at about $2 \mathrm{~h}$. In order to investigate the electro-reduction process of $\mathrm{Cu}_{2} \mathrm{~S}$, the reduction products obtained at different electrolysis stages were characterized by XRD. 


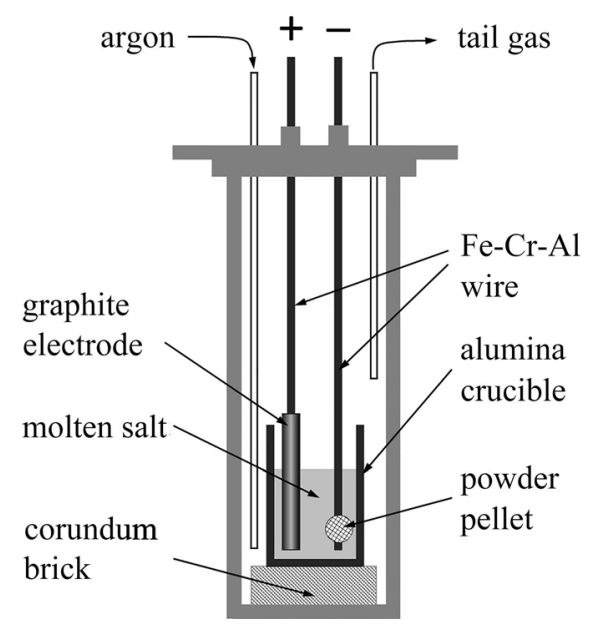

Figure 2. Schematic diagram of the electrolytic cell.

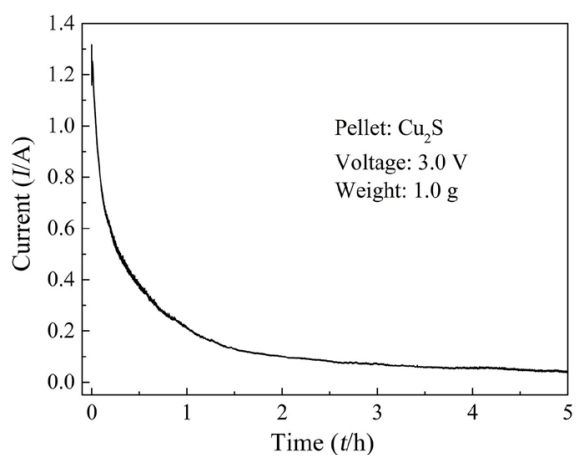

(a)

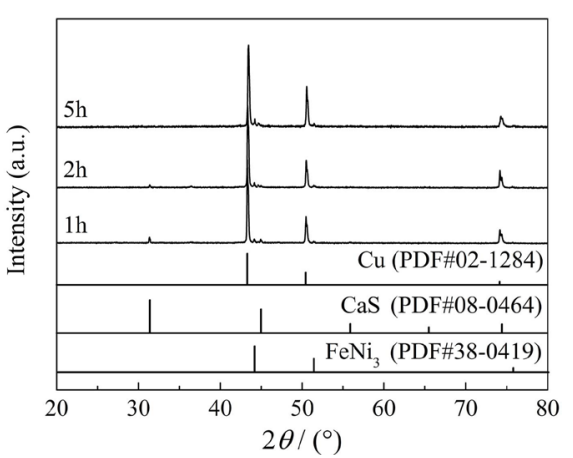

(b)

Figure 3. (a) Typical current-time curve of the electro-reduction of $\mathrm{Cu}_{2} \mathrm{~S}$ pellet at $3.0 \mathrm{~V}$ and $700^{\circ} \mathrm{C}$ in molten $\mathrm{CaCl}_{2}-\mathrm{NaCl}$; (b) XRD patterns of the products obtained from the electro-reduction of $\mathrm{Cu}_{2} \mathrm{~S}$ pellet at $3.0 \mathrm{~V}$ and $700^{\circ} \mathrm{C}$ for different times.

The XRD patterns of the $\mathrm{Cu}_{2} \mathrm{~S}$ pellets after being reduced at $3.0 \mathrm{~V}$ and $700^{\circ} \mathrm{C}$ for different times in molten $\mathrm{CaCl}_{2}-\mathrm{NaCl}$ are shown in Figure 3(b). It is seen that the phases of the sample obtained at $1 \mathrm{~h}$ include $\mathrm{Cu}, \mathrm{CaS}$ and $\mathrm{FeNi}_{3}$. Moreover, with the increase of electrolysis time, the peak intensity of $\mathrm{CaS}$ decreases evidently. According to the XRD patterns shown in Figure 3(b), copper with a small amount of $\mathrm{FeNi}_{3}$ obtained after being electrolyzed for more than $2 \mathrm{~h}$ at 3.0 V. According to the previous work [6], CaS has a low solubility in the salt melt and it will decompose into $\mathrm{Ca}^{2+}$ and $\mathrm{S}^{2-}$ as electrolysis proceeds further. $\mathrm{S}^{2-}$ will transport to the anode and then oxidize to form elemental sulphur. The electrode reactions for $\mathrm{Cu}_{2} \mathrm{~S}$ may be reasonably considered as:

$$
\begin{aligned}
& \text { Anodic reaction: } \mathrm{S}^{2-} \rightarrow 1 / 2 \mathrm{~S}_{2}(\mathrm{~g})+2 \mathrm{e}^{-} \\
& \text {Cathodic reaction: } \mathrm{Cu}^{+}+\mathrm{e}^{-} \rightarrow \mathrm{Cu}
\end{aligned}
$$

Figure 4 shows the SEM images of the $\mathrm{Cu}_{2} \mathrm{~S}$ pellets after being electrolyzed for $5 \mathrm{~h}$. Figure 4(b) is the partial enlarged detail showing the particles corresponding to Figure 4(a). After $5 \mathrm{~h}$ electrolysis, the pellet contains copper particles with 


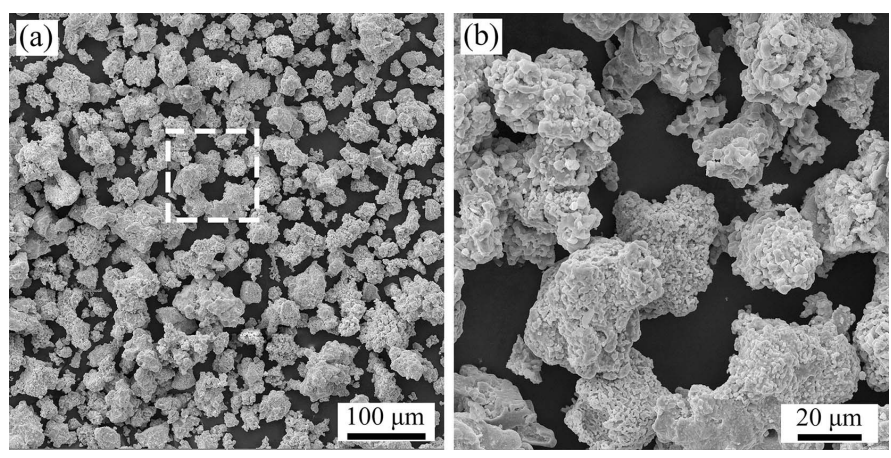

Figure 4. (a) SEM image of the $\mathrm{Cu}_{2} \mathrm{~S}$ pellet after being electro-reduced at $3.0 \mathrm{~V}$ and $700^{\circ} \mathrm{C}$ for $5 \mathrm{~h}$ in molten $\mathrm{CaCl}_{2}-\mathrm{NaCl}$, (b) the partial enlarged detail showing the particles in (a).

particle sizes of approximately $20 \mu \mathrm{m}$. Meanwhile, the obtained copper particles show rough surfaces and porous structures.

Figure 5(a) shows the typical current-time curve recorded during the electrolysis process of $\mathrm{Ni}_{3} \mathrm{~S}_{2}$. As shown in Figure 5(a), the current rapidly decreases within the first $30 \mathrm{~min}$. Then, the current decreases to a steady value at $1.5 \mathrm{~h}$. The products obtained at different electrolysis stages were characterized by using XRD. Figure $5(b)$ shows the XRD patterns of the $\mathrm{Ni}_{3} \mathrm{~S}_{2}$ pellets after being reduced at $3.0 \mathrm{~V}$ and $700^{\circ} \mathrm{C}$ for different times in molten $\mathrm{CaCl}_{2}-\mathrm{NaCl}$. The phases of the sample obtained at $1 \mathrm{~h}$ include $\mathrm{Ni}$ and CaS. Moreover, with the increase of electrolysis time, the peak intensity of $\mathrm{CaS}$ decreases evidently. Based on the result of the XRD analysis (Figure 5(b)), it is suggested that the electrolysis process of $\mathrm{Ni}_{3} \mathrm{~S}_{2}$ is similar to the electrolysis process of $\mathrm{Cu}_{2} \mathrm{~S}$, and the reactions may be expressed as:

$$
\begin{gathered}
\text { Anodic reaction: } \mathrm{S}^{2-} \rightarrow 1 / 2 \mathrm{~S}_{2}(\mathrm{~g})+2 \mathrm{e}^{-} \\
\text {Cathodic reaction: } \mathrm{Ni}^{2+}+2 \mathrm{e}^{-} \rightarrow \mathrm{Ni}
\end{gathered}
$$

Figure 6 shows the SEM images of the $\mathrm{Ni}_{3} \mathrm{~S}_{2}$ pellet after being electrolyzed for 5 h. Figure 6(b) is the partial enlarged detail showing the particles of Figure 6(a). Obviously, after $5 \mathrm{~h}$ electrolysis, the particles presents a complicated structure. Although most of the particles are irregular strips, the dendritic crystals can also be found in Figure 6. The particle size of the obtained nickel is significantly larger than that of the copper obtained under the same electrolysis conditions.

The current-time curve of the electrolysis process of converter matte is shown in Figure 7(a). Obviously, the current sharply drops within the first $20 \mathrm{~min}$. Then, the current decreases and reaches to a steady value at $2 \mathrm{~h}$. In comparison with the current-time curves shown in Figure 3(a) and Figure 5(a), it can be seen that the current-time curve of the electrolysis of converter matte is different. In the initial reaction period, the shape of the current-time curve shown in Figure 7(a) is similar to that of the current-time curve shown in Figure 5(a). The electrolysis process for the converter matte is mainly involved with the electro-reduction of $\mathrm{Ni}_{3} \mathrm{~S}_{2}$ and $\mathrm{Cu}_{2} \mathrm{~S}$. Therefore, after $1 \mathrm{~h}$ electrolysis, the shape of the 


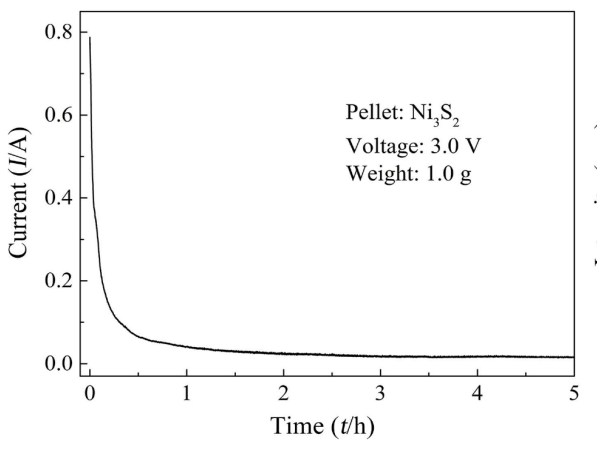

(a)

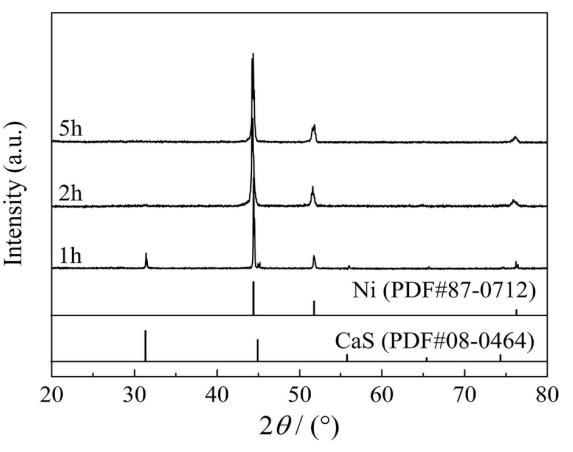

(b)

Figure 5. (a) Typical current-time curve of the electro-reduction of $\mathrm{Ni}_{3} \mathrm{~S}_{2}$ pellet at $3.0 \mathrm{~V}$ and $700^{\circ} \mathrm{C}$ in molten $\mathrm{CaCl}_{2}-\mathrm{NaCl}$, (b) XRD patterns of the products obtained from the electro-reduction of $\mathrm{Ni}_{3} \mathrm{~S}_{2}$ pellets at $3.0 \mathrm{~V}$ and $700^{\circ} \mathrm{C}$ in molten $\mathrm{CaCl}_{2}-\mathrm{NaCl}$.
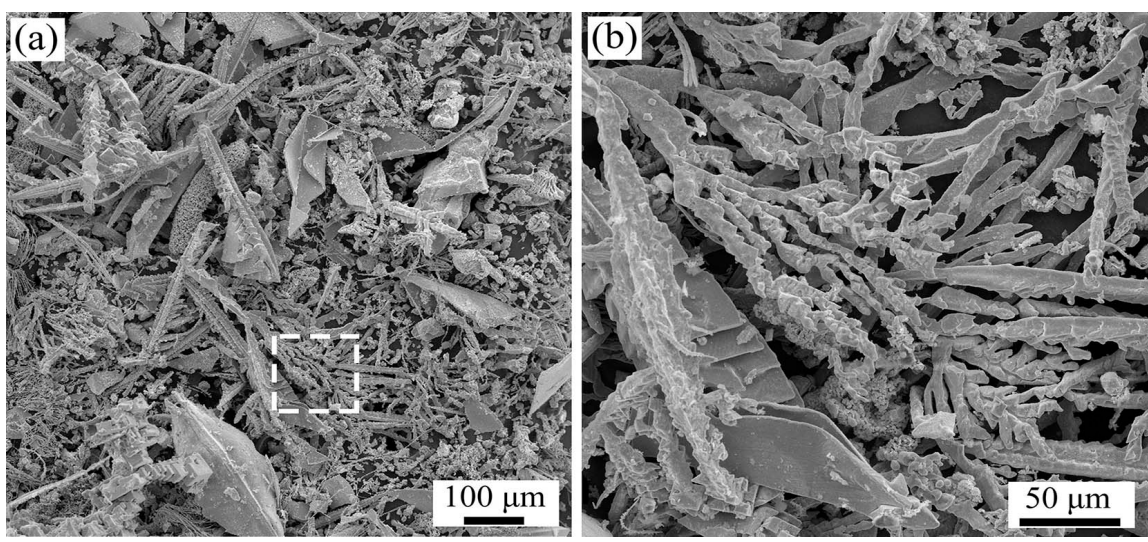

Figure 6. (a) SEM images of the $\mathrm{Ni}_{3} \mathrm{~S}_{2}$ pellets reduced at $3.0 \mathrm{~V}$ and $700^{\circ} \mathrm{C}$ in molten $\mathrm{CaCl}_{2}-\mathrm{NaCl}$ for $5 \mathrm{~h}$, (b) the partial enlarged detail showing the particles in (a).

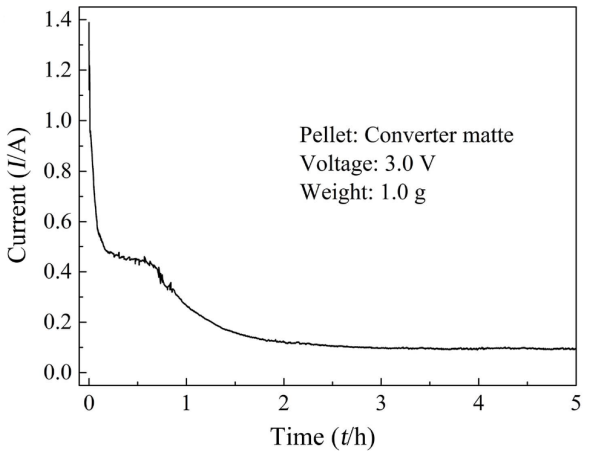

(a)

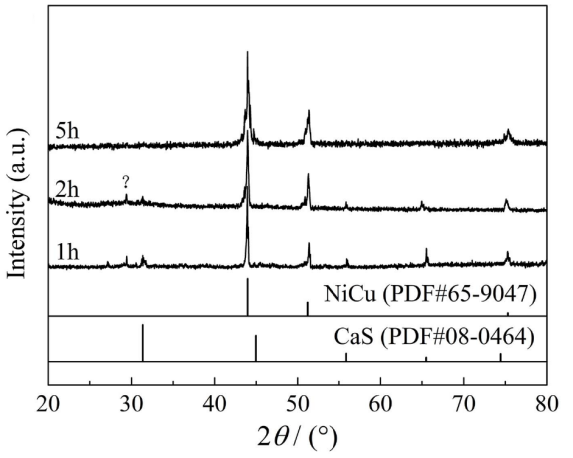

(b)

Figure 7. (a) Typical current-time curve of the electro-reduction of converter matte pellet at $3.0 \mathrm{~V}$ and $700^{\circ} \mathrm{C}$ in molten $\mathrm{CaCl}_{2}-\mathrm{NaCl}$, (b) XRD patterns of the products obtained from the electro-reduction of converter mattepellets at $3.0 \mathrm{~V}$ and $700^{\circ} \mathrm{C}$ in molten $\mathrm{CaCl}_{2}-\mathrm{NaCl}$.

current-time curve (Figure 7(a) from $1 \mathrm{~h}$ to $2 \mathrm{~h}$ ) is similar to that of the current-time curve shown in Figure 3(a). The XRD patterns of the converter matte pellets after being reduced at $3.0 \mathrm{~V}$ and $700^{\circ} \mathrm{C}$ for different times in molten 

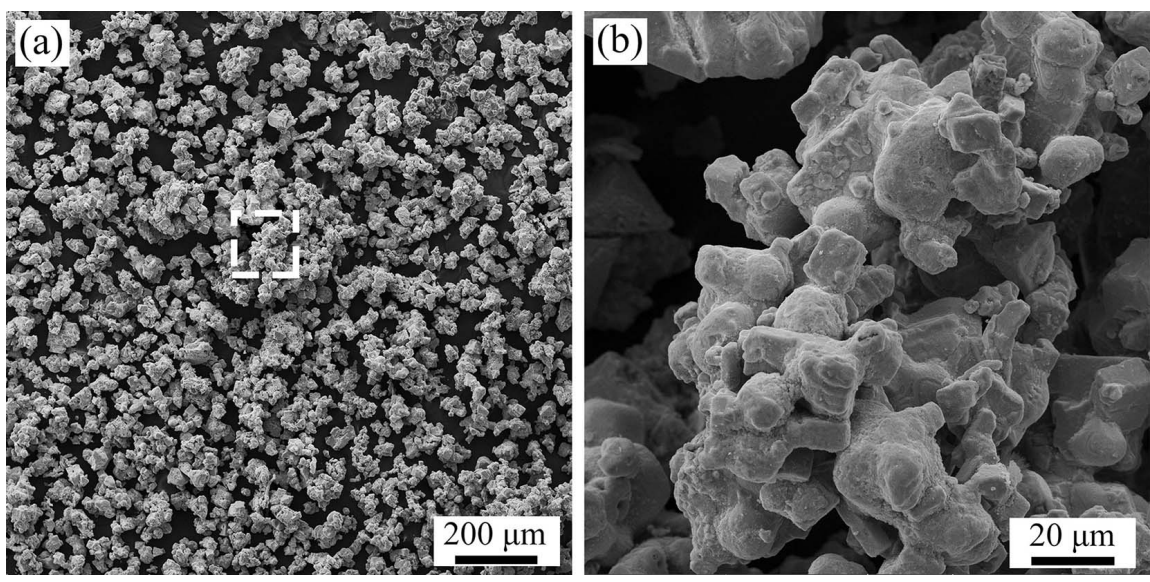

Figure 8. (a) SEM images of the converter matte pellet reduced at $3.0 \mathrm{~V}$ and $700^{\circ} \mathrm{C}$ in molten $\mathrm{CaCl}_{2}-\mathrm{NaCl}$ for $5 \mathrm{~h}$, (b) the partial enlarged detail showing the particles in (a).

$\mathrm{CaCl}_{2}-\mathrm{NaCl}$ are shown in Figure $7(\mathrm{~b})$. Obviously, the CaS peaks gradually decrease with the increasing electrolysis time, and the phase of the product obtained at $5 \mathrm{~h}$ is cubic nickel-copper $(\mathrm{NiCu})$ alloy. The reactions of the electro-reduction of converter matte can be expressed as:

$$
\begin{aligned}
& \text { Anodic reaction: } \mathrm{S}^{2-} \rightarrow 1 / 2 \mathrm{~S}_{2}(\mathrm{~g})+2 \mathrm{e}^{-} \\
& \text {Cathodic reactions: } \mathrm{Cu}^{+}+\mathrm{e}^{-} \rightarrow \mathrm{Cu} \\
& \mathrm{Ni}^{2+}+2 \mathrm{e}^{-} \rightarrow \mathrm{Ni} \\
& \mathrm{Ni}+\mathrm{Cu} \rightarrow \mathrm{NiCu}
\end{aligned}
$$

Figure 8 shows the SEM images of converter matte pellet after being electrolyzed at $3.0 \mathrm{~V}$ and $700^{\circ} \mathrm{C}$ for $5 \mathrm{~h}$. Figure 8 (b) is the partial enlarged detail showing the particles of Figure 8(a). After $5 \mathrm{~h}$ electrolysis, the pellet contains large interconnected particles. In comparison with the pure nickel and copper particles produced from $\mathrm{Ni}_{3} \mathrm{~S}_{2}$ and $\mathrm{Cu}_{2} \mathrm{~S}$ pellets, the $\mathrm{NiCu}$ alloy particles are more uniform and dense (Figure 8).

It should be noted that the electro-reduction process can produce sulphur element and $\mathrm{NiCu}$ alloy simultaneously. Considering there are several kinds of metals on the earth are present in the form of sulfides minerals, and the traditional extraction processes are complex. In addition, emission of $\mathrm{SO}_{2}$ is also a difficult problem due to the increased environmental restrictions. Therefore, the molten salt electro-reduction process may provide a promising strategy for the sustainable reduction of sulfides minerals.

\section{Conclusion}

The molten salt electro-reduction process has been used to extract nickel-copper alloy from converter matte in molten $\mathrm{CaCl}_{2}-\mathrm{NaCl}$. The results show that the sintered solid porous $\mathrm{Cu}_{2} \mathrm{~S}, \mathrm{Ni}_{3} \mathrm{~S}_{2}$ and converter matte pellets can be electrolyzed to copper, nickel and nickel-copper alloy under a voltage of $3.0 \mathrm{~V}$ at low temperature (approximately $700^{\circ} \mathrm{C}$ ), respectively. $\mathrm{CaS}$ would be formed as the intermediate product in the early electrolysis stage, and then $\mathrm{CaS}$ would be gradually 
decomposed. It is suggested that the molten salt electro-reduction process is a promising process for the facile and sustainable reduction of sulfide minerals.

\section{Acknowledgements}

The project was financially supported by the National Basic Research Program of China (No. 2014CB643403) and the National Natural Science Foundation of China (Nos. 51304132 and 51574164). We also thank the Instrumental Analysis and Research Center of Shanghai University for materials characterization.

\section{References}

[1] Chen, S., Brown, L., Levendorf, M., Cai, W., Ju, S.Y., Edgeworth, J., Li, X., Magnuson, C.W., Velamakanni, A., Piner, R.D., Kang, J., Park, J. and Ruoff, R.S. (2011) Oxidation Resistance of Graphene-Coated $\mathrm{Cu}$ and $\mathrm{Cu} / \mathrm{Ni}$ Alloy. ACS Nano, 5, 1321 1327. https://doi.org/10.1021/nn103028d

[2] Badawy, W.A., Ismail, K.M. and Fathi, A.M. (2006) Corrosion Control of Cu-Ni Alloys in Neutral Chloride Solutions by Amino Acids. Electrochimica Acta, 51, 4182-4189. https://doi.org/10.1016/j.electacta.2005.11.037

[3] Ghosh, S.K., Dey, G.K., Dusane, R.O. and Grover, A.K. (2006) Improved Pitting Corrosion Behaviour of Electrodeposited Nanocrystalline Ni-Cu Alloys in $3.0 \mathrm{wt} . \%$ $\mathrm{NaCl}$ Solution. Journal of Alloys and Compounds, 426, 235-243. https://doi.org/10.1016/j.jallcom.2005.12.094

[4] Kear, G., Barker, B.D., Stokes, K. and Walsh, F.C. (2004) Electrochemical Corrosion Behaviour of 90-10 Cu-Ni Alloy in Chloride-Based Electrolytes. Journal of Applied Electrochemistry, 34, 659-669. https://doi.org/10.1023/B:JACH.0000031164.32520.58

[5] Gonçalves, R.S., Azambuja, D.S. and Lucho, A.M.S. (2002) Electrochemical Studies of Propargyl Alcohol as corrosion Inhibitor for Nickel, Copper, and Copper/Nickel (55/45) Alloy. Corrosion Science, 44, 467-479. https://doi.org/10.1016/S0010-938X(01)00069-5

[6] Ge, X., Wang, X. and Seetharaman, S. (2009) Copper Extraction from Copper Ore by Electro-Reduction in Molten $\mathrm{CaCl}_{2}-\mathrm{NaCl}$. Electrochimica Acta, 54, 4397-4402. https://doi.org/10.1016/j.electacta.2009.03.015

[7] Warner, A.E.M., Diaz, C.M., Dalvi, A.D., Mackey, P.J., Tarasov, A.V. and Jones, R.T. (2007) JOM World Nonferrous Smelter Survey Part IV: Nickel: Sulfide. JOM, 59, 58-72. https://doi.org/10.1007/s11837-007-0056-X

[8] Cameron, R.A., Lastra, R., Mortazavi, S., Bedard, P.L., Morin, L., Gould, W.D. and Kennedy, K.J. (2009) Bioleaching of a Low-Grade Ultramafic Nickel Sulphide Ore in Stirred-Tank Reactors at Elevated pH. Hydrometallurgy, 97, 213-220. https://doi.org/10.1016/j.hydromet.2009.03.002

[9] Kirjavainen, V. and Heiskanen, K. (2007) Some Factors That affect Beneficiation of Sulphide Nickel-Copper Ores. Minerals Engineering, 20, 629-633. https://doi.org/10.1016/j.mineng.2007.01.001

[10] Yang, C., Qin, W., Lai, S., Wang, J., Zhang, Y., Jiao, F., Ren, L., Zhuang, T. and Chang, Z. (2011) Bioleaching of a Low Grade Nickel-Copper-Cobalt Sulfide Ore. Hydrometallurgy, 106, 32-37. https://doi.org/10.1016/j.hydromet.2010.11.013

[11] Barcan, V. (2002) Nature and Origin of Multicomponent Aerial Emissions of the Copper-Nickel Smelter Complex. Environment International, 28, 451-456. 
https://doi.org/10.1016/S0160-4120(02)00064-8

[12] Kojo, I.V., Jokilaakso, A. and Hanniala, P. (2000) Flash Smelting and Converting Furnaces: A 50 Year Retrospect. JOM, 52, 57-61. https://doi.org/10.1007/s11837-000-0049-5

[13] Moskalyk, R.R. and Alfantazi, A.M. (2002) Nickel Sulphide Smelting and Electrorefining Practice: A Review. Mineral Processing and Extractive Metallurgy Review, 23, 141-180. https://doi.org/10.1080/08827500306893

[14] Moskalyk, R.R. and Alfantazi, A.M. (2003) Review of Copper Pyrometallurgical Practice: Today and Tomorrow. Minerals Engineering, 16, 893-919.

https://doi.org/10.1016/j.mineng.2003.08.002

[15] Wang, T., Gao, H., Jin, X., Chen, H., Peng, J. and Chen, G.Z. (2011) Electrolysis of Solid Metal Sulfide to Metal and Sulfur in Molten NaCl-KCl. Electrochemistry Communications, 13, 1492-1495. https://doi.org/10.1016/j.elecom.2011.10.005

[16] Chen, G.Z., Fray, D.J. and Farthing, T.W. (2000) Direct Electrochemical Reduction of Titanium Dioxide to Titanium in Molten Calcium Chloride. Nature, 407, 361 364. https://doi.org/10.1038/35030069

[17] Fray, D.J. and Chen, G.Z. (2004) Reduction of Titanium and Other Metal Oxides using Electrodeoxidation. Materials Science and Technology, 20, 295-300. https://doi.org/10.1179/026708304225012242

[18] Ma, M., Wang, D., Wang, W., Hu, X., Jin, X. and Chen, G.Z. (2006) Extraction of Titanium from Different Titania Precursors by the FFC Cambridge Process. Journal of Alloys and Compounds, 420, 37-45. https://doi.org/10.1016/j.jallcom.2005.10.048

[19] Schwandt, C. and Fray, D.J. (2005) Determination of the Kinetic Pathway in the Electrochemical Reduction of Titanium Dioxide in Molten Calcium Chloride. Electrochimica Acta, 51, 66-76. https://doi.org/10.1016/j.electacta.2005.03.048

[20] Dring, K., Dashwood, R. and Inman, D. (2005) Voltammetry of Titanium Dioxide in Molten Calcium Chloride at $900{ }^{\circ} \mathrm{C}$. Journal of the Electrochemical Society, 152, E104-E113. https://doi.org/10.1149/1.1860515

[21] Alexander, D.T.L., Schwandt, C. and Fray, D.J. (2006) Microstructural Kinetics of Phase Transformations during Electrochemical Reduction of Titanium Dioxide in Molten Calcium Chloride. Acta Materialia, 54, 2933-2944. https://doi.org/10.1016/j.actamat.2006.02.049

[22] Yasuda, K., Nohira, T. and Ito, Y. (2005) Effect of Electrolysis Potential on Reduction of Solid Silicon Dioxide in Molten $\mathrm{CaCl}_{2}$. Journal of Physics and Chemistry of Solids, 66, 443-447. https://doi.org/10.1016/j.jpcs.2004.06.037

[23] Sakamura, Y., Kurata, M. and Inoue, T. (2006) Electrochemical Reduction of $\mathrm{UO}_{2}$ in Molten $\mathrm{CaCl}_{2}$ or LiCl. Journal of the Electrochemical Society, 153, D31-D39. https://doi.org/10.1149/1.2160430

[24] Abdelkader, A.M., Daher, A., Abdelkareem, R.A. and El-Kashif, E. (2007) Preparation of Zirconium Metal by the Electrochemical Reduction of Zirconium Oxide. Metallurgical and Materials Transactions B, 38, 35-44. https://doi.org/10.1007/s11663-006-9016-Z

[25] Kurata, M., Inoue, T., Serp, J., Qugier, M. and Glatz, J.P. (2004) Electro-Chemical Reduction of MOX in LiCl. Journal of Nuclear Materials, 328, 97-102. https://doi.org/10.1016/j.jnucmat.2004.03.013

[26] Xiao, W. and Wang, D. (2016) Rare Metals Preparation by Electro-Reduction of Solid Compounds in High-Temperature Molten Salts. Rare Metals, 35, 581-590. https://doi.org/10.1007/s12598-016-0778-4 
[27] Li, G., Wang, D., Jin, X. and Chen, G.Z. (2007) Electrolysis of Solid $\mathrm{MoS}_{2}$ in Molten $\mathrm{CaCl}_{2}$ for Mo Extraction without $\mathrm{CO}_{2}$ Emission. Electrochemistry Communications, 9, 1951-1957. https://doi.org/10.1016/j.elecom.2007.05.007

[28] Chen, G.Z. and Fray, D.J. (2001) Cathodic Refining in Molten Salts: Removal of Oxygen, Sulfur and Selenium from Static and Flowing Molten Copper. Journal of Applied Electrochemistry, 3, 155-164. https://doi.org/10.1023/A:1004175605236 